\title{
POPOSED MECHNISM FOR INSTITUTIONAL COORDINATION BETWEEN AGRICULTURAL EXTENTION, RESEARCHES ORGANIZATION AND AGRICULTURAL SERVES ORGANIZATIONS OPERATING IN THE GOVERNORATE OF HOLY KARBALA
}

\author{
R. M.Ismail \\ Assistant Prof \\ M. W AL - atwany \\ Researcher
}

Department of Agricultural Extension - College of Agriculture- University of Baghdad ABSTRACT

The research Milled I building proposed mechanism for institutional coordination between apicultural research and agricultural service ordain Faction operating in the 9 agricultural extension Governorate of Karbala, In order to achieve the objectives of the research, a questionnaire was prepared, including a five point scale consisting of (120) items distributed on (5) fields and (9) axes, the research was carried out in Karbala governorate on a random sample of $24 \%$ of the research Community, which is composed of 524 respondents thus the research sample become 126 respondents. By presenting the proposed mechanism on the sample of the research, the final forum was Weight mean greater reached using the following standard: the item remains in the final form if it get a than the proposed mean announced 3 degree. The result was survival of all the items within the final Construction of the coordination mechanism, as the field of evaluation ranked first in weighted mean of $(4$. 27degree, and then the implementation field with mean of 4.264 degree, then the monitor field weighted mean of 4. 24 degree, then the planning field with weighted mean of 4.21 degree, the field of organization carne last with weighted mean of 4.18 degree. The researcher recommends adopting the proposed mechanism in order to unite the possibilities and not to waste time and effort and reduce the cost and prevent conflict in the work of all parties related to Agricultural and rural development, bicultural service agencies

Keywords: coordination mechanism, agricultural research organizations,

Part of M.Sc, Thesis of the sound author

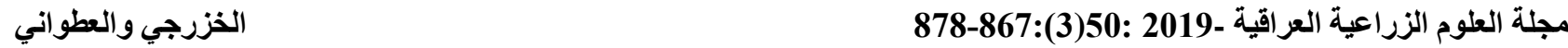

$$
\begin{aligned}
& \text { آلية مقترحة للتسيق المؤسسائي بين الإرشاد الزراعي والجهات البحثية والخدمية الزراعية العاملة في محافظة كربلاء المقدة } \\
& \text { محمد وحوح حسين العطواني } \\
& \text { باحث } \\
& \text { رعد مسلم اسماعيل الخزرجي } \\
& \text { استاذ مساعد } \\
& \text { جامعة بغداد - كلية الزراعة - قسم الإرشاد ونقل التقتيات الزراعية } \\
& \text { المستخلص }
\end{aligned}
$$




\section{INTRODUCTION}

Agricultural development is the most difficult task that a nation face, it Isa very complex issue, because it requires the participation of different scientific disciplines (9), The major obstacle to achieve it the multiplicity of agricultural development institutions, which haven't been accompanied by the institutional interclependence between them, which has made the production Sector lag behind the global developinent thus interclependence, in which the roles of these institutions are coordinated and integrated to serve develop (3). And that the green revolution was instilled in the minds of some of them in the belief that reliance on huge achievements in field of genetics, use of chemicals and other aspects of technological progress could achieve substantial increases that would enable elimination other aspects of agricultural development, including extension, a new research will continue to be a great value, but reliance on research alone is not enough to make the right progress, The assumption that the extension program is no longer needed after the success of a particular type of rice or wheat isa simplistic assumption (18). Agricultural extension is generally aimed at responding to the needs of all farmers categories in terms knowledge, skills and linkages between the firin and the market, in order to manage their farms effectively . Agricultural extension is not productive effectively if a unit works inclependently of linkages within farms chain to market (all employees) And its institutions (12). The greatest challenge is to adopt a multi - sectoral gricultural extension mechanism that effectively coordination the various nation face, it is a agricultural institutions, effectively coordination the various agricultural institutions, The absence of coordination leads to conflicts of works, activities and tasks, which weakens agricultural technologies discernination and related technical recommendations, that lead to confuse farmers and beneficiaries from these agricultural services, Governments should assure the responsibility for coordination and technical supervision (12). The lack of a close working relationship between agricultural research organizations and national agricultural extension agencies, farmer groups, and various agricultural organizations is one of most difficult | problems that facing of agriculture ministries in many developing countries (19). Several studies revealed the weak of coordination between agricultural agencies. Taha mentioned the weakness of the mechanism of communication and coordination between the extension agency and the developmental bodies contributing in the field of development, and there should be a new and effective mechanism for communication and coordination between all agricultural Organizations, especially related to a specific development guidance program for implemented (20). Al - Shammari pointed out that there should be a clear | and flexible mechanism for cooperation and coordination between agricultural organizations in general to avoid chaos in performance and to achieve tangible results on a large scale, especially with the subjects regard to the transfer of agricultural technologies (17). There is wide gap still between what researchers at research stations do and the rates of Production achieved by farmers in their fields (5). Also studies indicate a weakness between research institutions and extension, on improve the reality of rates production of farmers in their fields (12), so the link between them do not allow flow of scientific recommendations appropriately $(13,14)$. There are barriers to strengthening the relationship between extension, research and farmers (15). And the absence of an effective machining for communication and coordination in extension program development, which was caused by the absence of joint activities between them $(10,16,4)$. Al-Farhan suggested to establish a higher council for coordination between extension and research (6). The issue of agricultural development is complex and requires the participation of different scientific professional and institutional fields (9), with an interactive and interrelated relationship to results of scientific research and agricultural techniques(14). Therefore, the research came to answer the following research question : What are appropriate elements of mechanism for the development of institutional coordination among the actors in the 
agricultural production Sector, research objective is developing a proposed mechanism for institutional coordination between agricultural extension and agricultural researches and agricultural service organizations providers operating in Karbala governorate, and to determine the level of consent of the respondents to the proposed mechanism.

\section{MATERIALS AND METHODS}

The research is assume approval of respondents on elements of proposed mechanism of institutional coordination between the agricultural extension, agricultural researches and agricultural services. That because of the proposed mechanism is effecting in agriculture development achievement. The researcher was used the descriptive method in conducting the research. The descriptive approach is concerned with describe the phenomenon or the subject of the research interest as a precise scientific description and was trying investigate solutions and interpretations based on the results of the data and information research community :

The research cornrnunity was including employers in agricultural institutions in the following: Technical staff of the directorate agriculture of Karbala in all its eight agricultural divisions (Center, Husseiniya , Tuwerij, Aoun, ALjadwal ALgaraby, Khairat, Ain Al - Tamr and Sahrawi), colleges of agriculture professors and Veterinary Medicine at Karbala university, researchers of agricultural researches office, agricultural extension training center state company for agricultural supplies, Mesopotamia state company for seeds, the agricultural cooperation Bank sthe horticulture station, the palm research Station. A random sample was selected from the Research population that announced (524) respondents by (24\%). Thus, the sample of research (126) was studied and distribution (Table 1).

\begin{tabular}{|c|c|c|c|}
\hline No & Workplace & Community & Sample \\
\hline 1 & Agricultural directorate of Karbala & 204 & 49 \\
\hline 2 & Agricultural extension centre & 25 & 6 \\
\hline 3 & agricultural research office & 82 & 20 \\
\hline 4 & Collage of agriculture & 41 & 10 \\
\hline 5 & college of Veterinary Medicine & 30 & 7 \\
\hline 6 & Veterinary Department & 80 & 19 \\
\hline 7 & Private agricultural companies & 42 & 10 \\
\hline 8 & State company for agricultural supplies and Mesopotamia state company for seeds & 7 & 2 \\
\hline 9 & Horticulture Station & 5 & 1 \\
\hline 10 & Palm Research Station & 4 & 1 \\
\hline \multirow[t]{2}{*}{11} & Agricultural cooperation Bank & 4 & 1 \\
\hline & 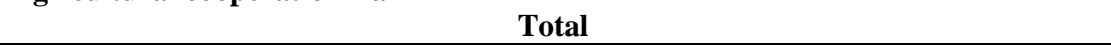 & 524 & 126 \\
\hline
\end{tabular}

The survey questionnaire was prepared as a tool for collecting data to the proposed mechanism for institutional coordination between agricultural extension, agricultural researches, and agricultural service originations, The questionnaire included scale on the way to measure approval of respondents on proposed mechanism for institutional coordination. The questionnaire was passed on several stages to achieve ultimately form as exposed below First: Configure the primary form scale The primary form scale was configured in light of literature and previous studies in the field of coordination, relationship and links between various institutions related with agricultural production, the scale consisted of five fields and nine axes : first, organization which consists of three axes that are: organizational | structure, responsibilities and duties, job deseeration of the addrministrative coordinators. second plannins which consists of six axes : development Need for planning, organization for planning, mechanism of the work, participation, communication and publication, actual planning. Third, implementation, forth, monitor. Fifth, evaluation. The number of items was amounted (120) items distributed in fields and axes mentioned above ( $35,50,14,10,11$ ) respectively, as reveal in Table 2 
Table 2 . The distribution of fields, axes and items of the proposed mechanism of institutional coordination

\begin{tabular}{|c|c|c|c|c|}
\hline No & Fields & Axes & The number of items & $\%$ \\
\hline \multirow[t]{3}{*}{1} & Organization & 1.organizational structure & 12 & $\mathbf{1 0}$ \\
\hline & & 2.Tasks and duties & 16 & 13.3 \\
\hline & & 3 - job descriptions for administrative coordinators & 7 & 5.8 \\
\hline \multirow[t]{6}{*}{2} & Planning & 1 - development of the need for planning 2.organization & 6 & 5 \\
\hline & & for planning & 5 & 4.2 \\
\hline & & 3. mechanism of work & 10 & 8.3 \\
\hline & & 4. participation & 7 & 5.8 \\
\hline & & 5. communication and publication & 12 & 10 \\
\hline & & 6. actual planning & 10 & 8.3 \\
\hline 3 & Implementation & & 14 & 11.7 \\
\hline 4 & Monitor & & 10 & 8.3 \\
\hline 5 & Evaluation & & 11 & 9.2 \\
\hline Total & & & 120 & 100 \\
\hline
\end{tabular}

\section{Second: Developing the scale}

The initial scale was presented to a group of experts and specialists in the field of agricultural extension and public administration (16) experts using a questionnaire to indicate the degree of their approval in the light of the approval scale of three levels are agree, agree with the amendment, and disagree . The purpose of presenting the initial measure to the experts is to examine the apparent truthfulness of looking for what the test seems to measure (21), as well as the validity of the content, which is the knowledge of measuring each of the test items for the content of the material to be measured Thirdly: The scale is finalized The scale was finally constructed by comparing the scores of the experts ' approval on the fields, axes, and items of the scale with the cutting threshold, All the items achieved $75 \%$ or reaching the cutting threshold $(90 \%)$. The number of iterns of the scale ( 116 ) distributed on ( 9 ) Xes Indi ( 5 ) areas, and thus achieve the first goal of the research through created of the final| version of the scale for the proposed mechanism. Sample of 14 respondents outside the research sample was selected to check research stability by pre - test to the scale, and Kronbach coefficient used to scale stability measurement, that is scientifically acceptable if it announted 0.80 and above (8), All fields and axes for the proposed mechanism institutional coordination has kronbach coefficient more than 0.80 , this means getting the same result if re - test regardless of the date of the test or how different the analysts (1) . as shows in Table 3.

Table3. Kronbach coefficient for fields of the mechanism institutional coordination

\begin{tabular}{|lll|}
\hline No & Scale & Kronbach coefficient \\
\hline 1 & Organization & 0.95 \\
2 & planning & 0.96 \\
3 & Implement & 0.94 \\
4 & monitor & 0.85 \\
5 & Evaluation & 0.93 \\
6 & Mechanism institutional coordination & 0.93 \\
\hline
\end{tabular}

Research data was collected by the questionnaire throughout the personal interview with respondents at the period (30/ 12 / 2016 - 28 / 02 / 2017). After the data were collected and, data was analyzed using manual analysis, and used the statistical analysis (SPSS) program to measure the stability coefficient, the respondents approval of the fundamentals of the proposed ineclianismn was measured on a five - point scale consisting of ( very agree, gree, neutral, disagree, very disagree) and was give value of (5.4.3.2.1) respectively. The researcher used the percentage weight weighted average and the Cronbach coefficient

\section{RESULTS AND DISCUSSION}

First Objective: preparing the proposed mechanism to institutional coordination between the agricultural extension, the research organizations, and the service providers for agricultural development. The proposed mechanism intended for institutional coordination was achieved as mentioned above on the methodology by presenting the scales elements to experts in the fields of weight ranging for agricultural extension and 
management, and produced the scales final version.Second Objective: determination level of respondents' approval of the proposed mechanism for institutional coordination between agrictureal Extension, research Organizations and the service providers of agricultural development.

1 - The organization field:

Table 4, distribution of the respondents according to the proposed items of the organization field

\begin{tabular}{|c|c|c|c|c|c|}
\hline Axes & $\begin{array}{c}\text { Sort of } \\
\text { items as } \\
\text { importan } \\
t\end{array}$ & Items & $\begin{array}{l}\text { Number of } \\
\text { items in } \\
\text { questionnaire }\end{array}$ & $\begin{array}{l}\text { Weighte } \\
\text { mean }\end{array}$ & $\begin{array}{l}\text { Percent age } \\
\text { weight }\end{array}$ \\
\hline \multirow[t]{10}{*}{$\begin{array}{l}\text { 1- } \\
\text { Organization } \\
\text { structure }\end{array}$} & 1 & $\begin{array}{l}\text { The members of the Division shall be Competent and skilled in } \\
\text { communicating with others and gaining their trust and . Sustaining the } \\
\text { relationship with them }\end{array}$ & 8 & 4.444 & 88.88 \\
\hline & 2 & $\begin{array}{l}\text { The members of the Division shall be familiar with the extension } \\
\text { approaches that adopt coordination and partnership between the various } \\
\text { bodies involved in agricultural production }\end{array}$ & 7 & 4.3288 & 87.76 \\
\hline & 3 & $\begin{array}{l}\text { The members of the division shall have a degree in agricultural sciences } \\
\text { and preferably in agricultural extension }\end{array}$ & 6 & 4.230 & 84.6 \\
\hline & 4 & $\begin{array}{l}\text { Establishment of an administrative organization in the Directorate of } \\
\text { Agriculture and a level of division in the Department of Extension and } \\
\text { Agricultural Training called the Institutional Coordination Division }\end{array}$ & 1 & 4.214 & 84.28 \\
\hline & 5 & $\begin{array}{l}\text { Nominating an administrative coordinator from all research, educational } \\
\text { service, private agricultural companies, farmers and their } \\
\text { Organizations in the governorate }\end{array}$ & 9 & 4.150 & 83 \\
\hline & 6 & $\begin{array}{l}\text { The Institutional Coordination Division is directly associated with the } \\
\text { head of the Agricultural Extension and Training Section }\end{array}$ & 2 & 4.071 & 81.42 \\
\hline & 7 & $\begin{array}{l}\text { The number of employees in the division ( } 6 \text { ) shall be three facilitators } \\
\text { and three specialists }\end{array}$ & 5 & 3.857 & 77.14 \\
\hline & 8 & $\begin{array}{l}\text { The Guidance Center in the governorate is represented in the Division by } \\
\text { the Under - Secretary of the Center }\end{array}$ & 10 & 3.825 & 76.5 \\
\hline & 9 & $\begin{array}{l}\text { The Division is subject to the central directives of the Ministry of } \\
\text { Agriculture and the Agricultural ComTimmittee of the Provincial Council } \\
\text { and the Directorate of Agriculture of Karbala through the Director of } \\
\text { Agriculture and Head of Agricultural Extension Department }\end{array}$ & 3 & 3.809 & 76.18 \\
\hline & 10 & $\begin{array}{l}\text { The authority of the Division shall be delegated by the Director of } \\
\text { Agriculture }\end{array}$ & 4 & 3.730 & 74.6 \\
\hline \multirow{14}{*}{$\begin{array}{l}\text { 2-task and } \\
\text { duties }\end{array}$} & 1 & Continued coordination with farmers and their organizations & 12 & 4.484 & 89.68 \\
\hline & 2 & $\begin{array}{l}\text { Coordination with agricultural service institutions in the governorate ( } \\
\text { state company for agricultural supplies, agricultural rant in bark, } \\
\text { Mesopotamia state company for seeds palm station, plant tissue culture, } \\
\text { plant protection, animal recourse department of veterinary and fish }\end{array}$ & 10 & 4.412 & 88.24 \\
\hline & 3 & $\begin{array}{l}\text { Building links and rdination with agricultural research educational } \\
\text { institutions in the governorate ( Faculty of Agriculture, Faculty of } \\
\text { Veterinary medicine) }\end{array}$ & 9 & 4.404 & 88.24 \\
\hline & 4 & $\begin{array}{l}\text { The Division coordinates the efforts possibilities available to research and } \\
\text { service institutions, extension agencies farmers and their organizations lo } \\
\text { Produce, transfer and disseminate agricultural techniques and scientific } \\
\text { reeminhenslations }\end{array}$ & 13 & 4.341 & 86.82 \\
\hline & 5 & $\begin{array}{l}\text { coordinate and approve agricultural technology dissemination plans and } \\
\text { programs }\end{array}$ & 4 & 4.341 & 86.82 \\
\hline & 6 & $\begin{array}{l}\text { The Division coordinates with agricultural research institutions ( stations, } \\
\text { centers, research projects and agricultural development programs ) }\end{array}$ & 8 & 4.285 & 85.7 \\
\hline & 7 & $\begin{array}{l}\text { The Coordination Division assists researchers in establishing contact with } \\
\text { farmers to invest local sources of information and to provide information } \\
\text { on prevailing agricultural practices }\end{array}$ & 17 & 4.277 & 85.54 \\
\hline & 8 & $\begin{array}{l}\text { Developing the mechanism of the flow of productive problems and } \\
\text { solutions among farmers, research centers, universities and agricultural } \\
\text { extension }\end{array}$ & 2 & 4.253 & 85.06 \\
\hline & 9 & $\begin{array}{l}\text { The Division works to strengthen the sense of the need for coordination } \\
\text { the extension, research and service providers, farmers and their local } \\
\text { organizations }\end{array}$ & 14 & 4.246 & 84.92 \\
\hline & 10 & Cordination with private agricultural companies in the governorate & 11 & 4.412 & 84.92 \\
\hline & 11 & Request for financial locations for institutional ordination processes & 5 & 4.206 & 84.12 \\
\hline & 12 & $\begin{array}{l}\text { The Division is preparing integrated information system with continuous } \\
\text { updating on the research, extension }\end{array}$ & 16 & 4.198 & 83.96 \\
\hline & 13 & $\begin{array}{l}\text { Building links with international regional supporting agricultural and } \\
\text { research projects }\end{array}$ & 18 & 4.166 & 83.32 \\
\hline & 14 & $\begin{array}{l}\text { The Division is preparing a program stimulate research, extension, service } \\
\text { and farmers to participate in coordination activities. }\end{array}$ & 15 & 4.150 & 83 \\
\hline
\end{tabular}




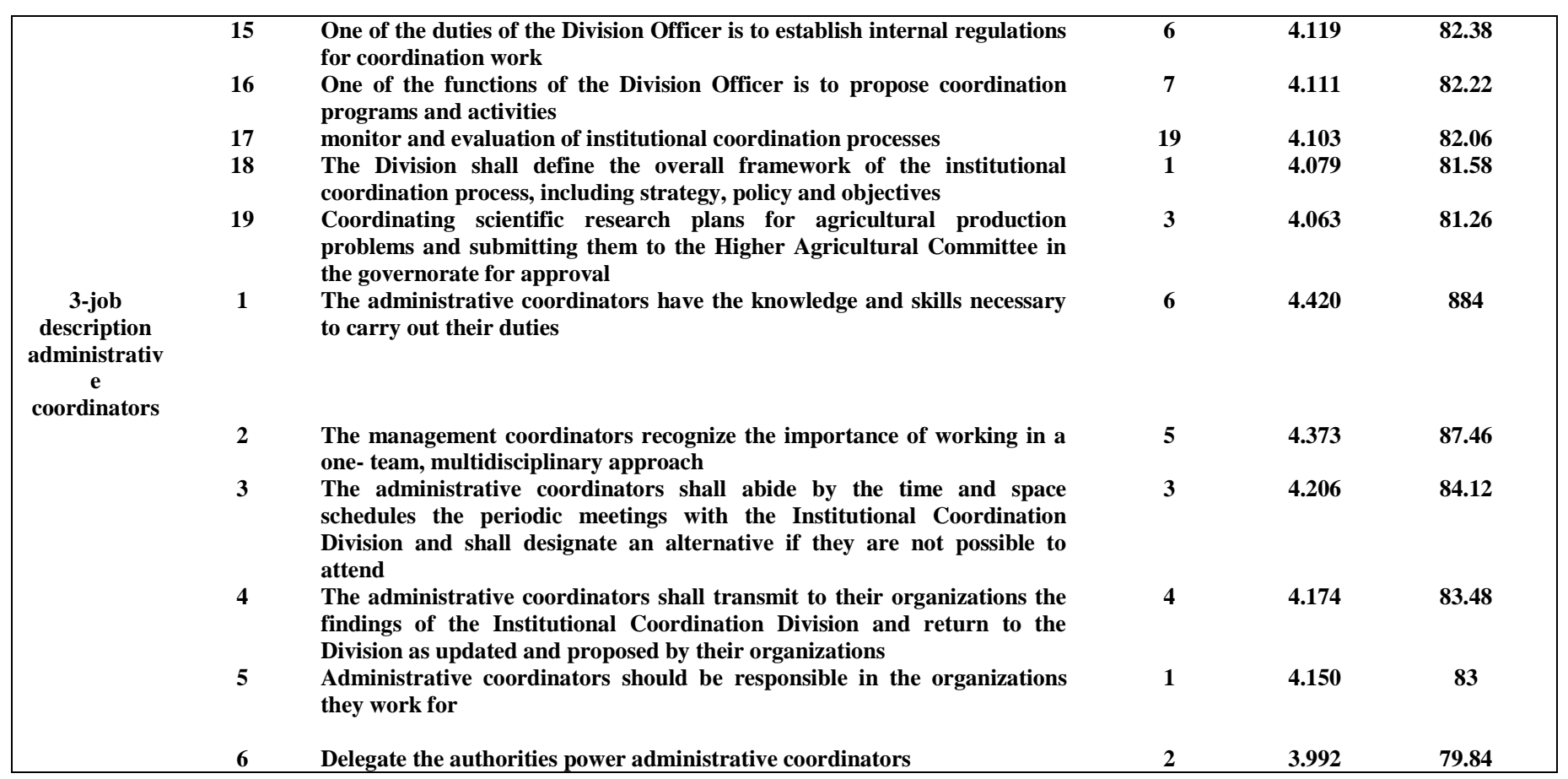

Table 4 indicates that item (continuous coordination with farmers shall be delegated by the Director of and their organizations ) has come in Agriculture ) has come in the last place first place perhaps because the respondents believe that farmers and their organizations as the center of agricultural production, where agricultural extension efforts are directed towards raising there economic and social level, achieving agricultural and rural development and achieving food security, while the item (The authority of the Division ) has came in the last place, this may be due tow the lack of confidence in the capacities of agricultural extension workers in addition to the centralism and bureaucracy, and the fact that most of the employees are in employed by carrying out a series of orders from bosses at work.

2- Planning field :

taking into consideration the results of the respondents' responses, all items getting weighted mean ranging (3.730 coordination mechanism, the same as - 4.484) and getting percentage weight ranging 74.6-89.68), for that all items remain within the final version of the proposed institutional shown in the table (5) below.

Table 5. Distribution of the respondents according to the proposed items of the planning fiel

\begin{tabular}{|c|c|c|c|c|c|}
\hline Axes & $\begin{array}{l}\text { Number of } \\
\text { item as } \\
\text { important }\end{array}$ & Item & $\begin{array}{l}\text { Number of } \\
\text { items in } \\
\text { questionnaire }\end{array}$ & Weighte mean & $\begin{array}{l}\text { Percent age } \\
\text { weighte }\end{array}$ \\
\hline \multirow[t]{6}{*}{$\begin{array}{l}\text { 1-Development } \\
\text { need for } \\
\text { planning }\end{array}$} & 1 & $\begin{array}{l}\text { Institutional coordination among the extension, } \\
\text { research and service providers, farmers and their local } \\
\text { organizations should increase production and improve } \\
\text { farm incom }\end{array}$ & 1 & 4.468 & 89.36 \\
\hline & 2 & $\begin{array}{l}\text { Institutional coordination between the agricultural } \\
\text { extension, research and service providers, farmers and } \\
\text { their local organizations should contribute to the } \\
\text { creation of sustainable rural development }\end{array}$ & 2 & 4.404 & 88.08 \\
\hline & 3 & $\begin{array}{l}\text { coordination planning policy should be written, clear } \\
\text { and accessible to all and encourage coordination and } \\
\text { partnership }\end{array}$ & 3 & 4.357 & 87.14 \\
\hline & 4 & $\begin{array}{l}\text { The coordination plans for the establishment of } \\
\text { research and extension programs depend on the } \\
\text { participation of farmers and beneficiaries, especially } \\
\text { in the problem identification phase }\end{array}$ & 4 & 4.277 & 85.54 \\
\hline & 5 & $\begin{array}{l}\text { The philosophy of the Division stems from the } \\
\text { environment surrounding farms systems considering } \\
\text { the social reality, economic, cultural realities }\end{array}$ & 5 & 4.214 & 84.28 \\
\hline & 6 & $\begin{array}{l}\text { Adopting a coordination strategy derived from the } \\
\text { strategies of the Ministry of Agriculture considering } \\
\text { the agricultural specialization in the governorate }\end{array}$ & 6 & 4.190 & 83.8 \\
\hline $\begin{array}{l}2- \\
\text { Organization } \\
\text { for planning }\end{array}$ & 1 & $\begin{array}{l}\text { The plan of coordination should include financial, } \\
\text { material, and supplies planning for activities and } \\
\text { extension activities aimed at transferring and } \\
\text { disseminating the results of research programs and }\end{array}$ & 4 & 4.182 & 83.64 \\
\hline
\end{tabular}




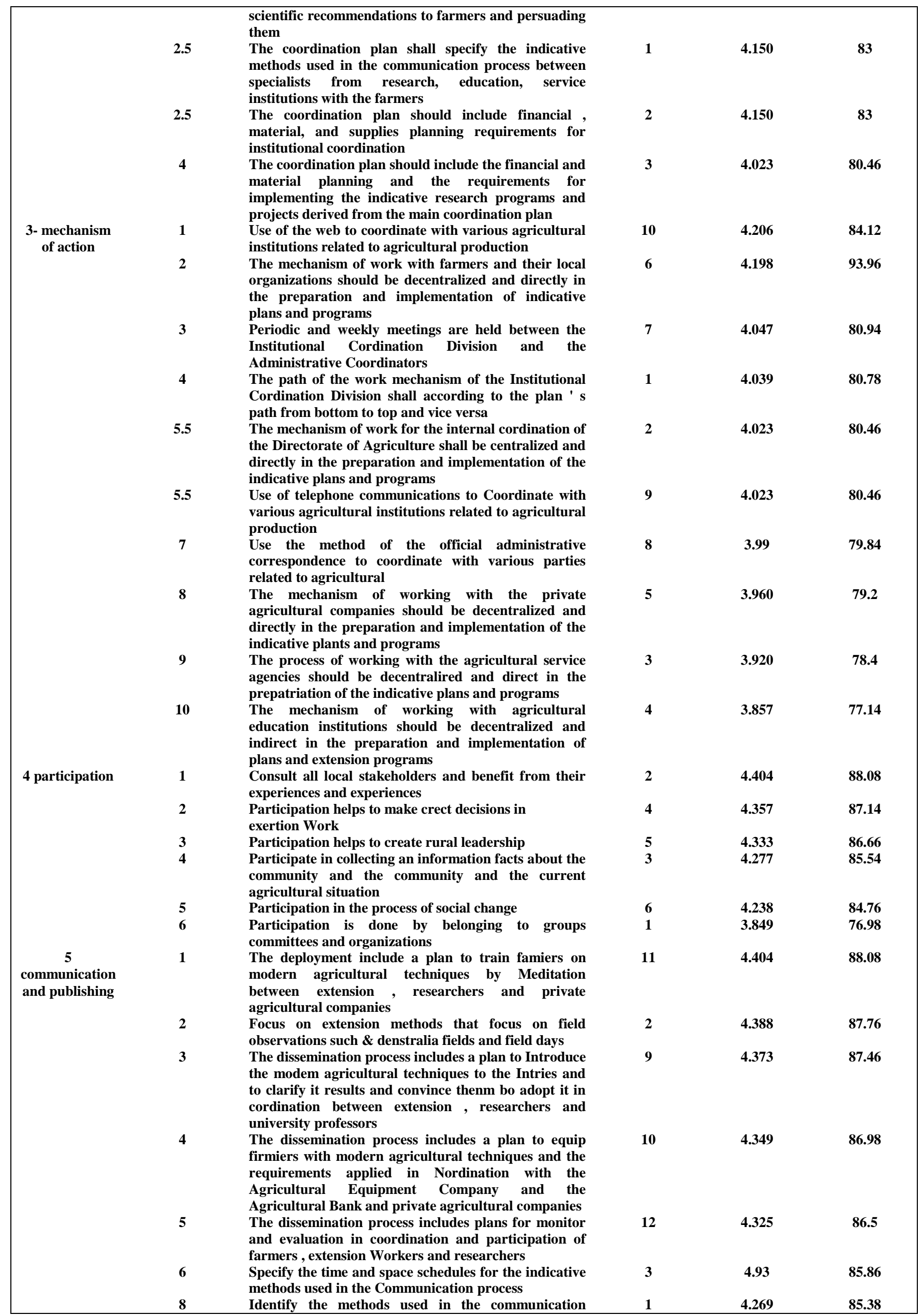




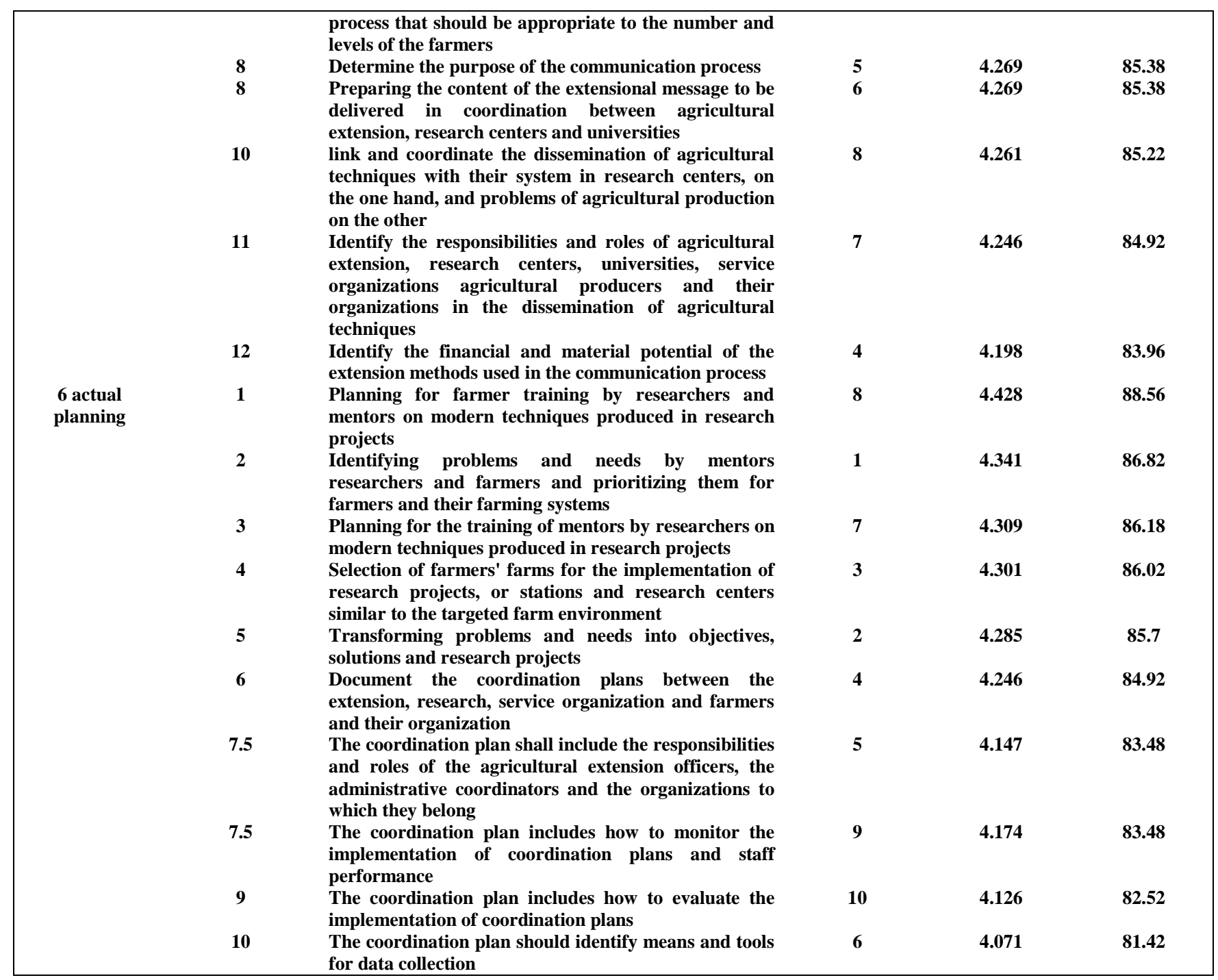

XTable 5 deduces that item the main objective of planning the Institutional coordination among the coordination process extension, research and service providers, farmers and their local organizations (Participation is done by belonging to should increase production and improve farm income ) has come in the first place this may be attributed to the respondents' de to the respondents' belief in the belief that increasing agricultural failure of previous experiences of the production and improving farm income is to which all efforts and potential while the item groups, committees and organizations) has come in the last place, this may be infliction of contagion in Karbala governorate in groups and associations due to various reasons, such as the lack of sufficient support for the continuation of these associations

3- implementation field:

taking into consideration the results of the respondent's responses all items getting weighted mean ranging (4.015- getting 4.380), and getting percentage weight ranging (80.387.6) for that all items, remain within the final version of the respondents responses, all items proposed institutional coordination mechanism, the same as shows in the Table 6 . 
Table 6. Distribution of the respondents according to the proposed items of the implementation field

\begin{tabular}{|c|c|c|c|c|}
\hline $\begin{array}{c}\text { Number of item as } \\
\text { important }\end{array}$ & Item & $\begin{array}{c}\text { Number of } \\
\text { items in } \\
\text { questionnaire }\end{array}$ & Weight mean & $\begin{array}{c}\text { Percent age } \\
\text { weight }\end{array}$ \\
\hline 1 & $\begin{array}{l}\text { Coordinating the implementation of field days for } \\
\text { the dissemination of modern agricultural techniques }\end{array}$ & 8 & 4.380 & 87.6 \\
\hline 2 & $\begin{array}{l}\text { Coordination with the Agricultural Bank to provide } \\
\text { loans to farmers }\end{array}$ & 12 & 4.373 & 87.46 \\
\hline 3 & $\begin{array}{l}\text { Coordinating with the research institutions to train } \\
\text { farmers to apply modern agricultural technologies } \\
\text { correctly }\end{array}$ & 14 & 4.349 & 86.98 \\
\hline 4 & $\begin{array}{l}\text { Coordinating with private agricultural companies to } \\
\text { produce modern technologies and distribute them to } \\
\text { farmers at suitable prices }\end{array}$ & 11 & 4.341 & 86.82 \\
\hline 5 & $\begin{array}{l}\text { Coordinating the implementation of demonstration } \\
\text { fields for the dissemination of modern agricultural } \\
\text { techniques and the scientific recommendations } \\
\text { resulting from extension research programs and } \\
\text { projects with the participation of researchers, } \\
\text { extension workers and farmers }\end{array}$ & 6 & 4.333 & 86.66 \\
\hline 6 & $\begin{array}{l}\text { Coordinating with researchers and specialists to } \\
\text { prepare the scientific material for agricultural } \\
\text { extension brochures and posters }\end{array}$ & 9 & 4.325 & 86.5 \\
\hline 7.5 & $\begin{array}{l}\text { Coordination for the implementation of agricultural } \\
\text { extension meetings with the participation of } \\
\text { researchers, extension workers and farmer }\end{array}$ & 7 & 4.317 & 86.34 \\
\hline 7.5 & $\begin{array}{l}\text { The division provides office and field consultations } \\
\text { to the farmers }\end{array}$ & 13 & 4.317 & 86.34 \\
\hline 9 & $\begin{array}{l}\text { Provide researchers with feedback and farmers' } \\
\text { reactions to modern agricultural techniques } \\
\text { resulting from research projects }\end{array}$ & 15 & 4.309 & 86.18 \\
\hline 10 & $\begin{array}{l}\text { Preparation of scientific material for the methods of } \\
\text { public communication via radio and television by } \\
\text { agricultural extension workers, researchers and } \\
\text { professors of the Faculties of Agriculture and } \\
\text { Veterinary Medicine }\end{array}$ & 10 & 4.285 & 85.7 \\
\hline 11 & $\begin{array}{l}\text { Preparing field studies and collecting data and } \\
\text { information on targeted agricultural areas with the } \\
\text { participation of agricultural extension workers } \\
\text { researchers and farmers }\end{array}$ & 3 & 4.214 & 84.28 \\
\hline 12 & $\begin{array}{l}\text { Conducting adaptive and adaptive experiments of } \\
\text { modern agricultural techniques resulting from } \\
\text { research programs and projects in agricultural } \\
\text { fields with the participation of researchers, } \\
\text { extension workers and farmers }\end{array}$ & 5 & 4.150 & 83 \\
\hline 13 & $\begin{array}{l}\text { The Division implements approved plans for } \\
\text { institutional coordination between agricultural } \\
\text { extension, agricultural scientific research } \\
\text { agricultural service providers and the farmers }\end{array}$ & 1 & 4.142 & 82.84 \\
\hline 14 & $\begin{array}{l}\text { The Division shall implement approved plans } \\
\text { generation and transfer of modern agricultural } \\
\text { techniques }\end{array}$ & 2 & 4.111 & 82.22 \\
\hline 15 & $\begin{array}{l}\text { Testing of modern agricultural techniques resulting } \\
\text { from research programs and projects in farmers } \\
\text { fields }\end{array}$ & 4 & 4.015 & 80.3 \\
\hline
\end{tabular}

Table 6 reveals that item (Coordinating the implementation of field days for the dissemination of modern agricultural techniques ) was ranked first, may be due to the importance attributed by the respondents to the field days, as one of the best agricultural extension methods in the dissemination of agricultural technologies, because it include practical application of these technologies in farmers fields 'while the item ( Testing of modern agricultural techniques resulting from research programs and projects in farmers fields ) has come in the last place, this may be due to the respondents ' dissatisfaction with the possibility of testing modern agricultural techniques resulting from research programs and projects in farmers ' fields, because they had not seen it previously .

4 - Monitor field:

Taking into consideration the results of the respondents ' responses, all items getting weighted mean ranging (4 . $126-4.412)$, and getting percentage weight ranging (82.52-88 . 24), for that all Items remain within the final version of the proposed institutional coordination mechanism, the same as shows in the Table 7. 
Table 7. Distribution of the respondents according to the proposed items of the monitor field

\begin{tabular}{|c|c|c|c|c|}
\hline $\begin{array}{c}\text { Number of item as } \\
\text { important }\end{array}$ & Item & $\begin{array}{l}\text { Number of items in } \\
\text { questionnaire }\end{array}$ & Weight mean & $\begin{array}{c}\text { Percentage } \\
\text { weight }\end{array}$ \\
\hline 1 & $\begin{array}{l}\text { Monitor to provide farmers with the necessary } \\
\text { information using modern technologies and applying } \\
\text { scientific recommendations }\end{array}$ & 7 & 4.412 & 88.24 \\
\hline 2 & $\begin{array}{l}\text { Verification of farmers ' application of scientific } \\
\text { recommendations correctly }\end{array}$ & 6 & 4.309 & 86.18 \\
\hline 3 & $\begin{array}{l}\text { Diagnosis of deviation and problems in the } \\
\text { implementation of approved plans and work to } \\
\text { correct them }\end{array}$ & 3 & 4.277 & 85.54 \\
\hline 4 & $\begin{array}{l}\text { Verification the availability of new technologies } \\
\text { resulting from research projects and the } \\
\text { requirements of applying scientific recommendations } \\
\text { at the appropriate prices, times and places }\end{array}$ & 5 & 4.206 & 83.8 \\
\hline 5 & $\begin{array}{l}\text { responsible for monitoring the implementation of } \\
\text { approved coordination plans through field visits to } \\
\text { the implementation sites and periodic progress } \\
\text { reports }\end{array}$ & 1 & 4.19 & 83.8 \\
\hline 6 & $\begin{array}{l}\text { Development of a mechanism to verify the orderly } \\
\text { flow of data and information from the } \\
\text { implementation sites to the Institutional } \\
\text { Coordination Division }\end{array}$ & 2 & 4.166 & 83.32 \\
\hline 7 & $\begin{array}{l}\text { Verify of Implementation matching of approved } \\
\text { plans }\end{array}$ & 4 & 4.126 & 82.52 \\
\hline
\end{tabular}

Table 7 reveals that item ( Monitor to provide farmers with the necessary information using modern technologies and applying scientific recommendations) was ranked first, this may be due to the respondents ' great importance to the monitor of farmers ' use of these technologies to avoid errors resulting from their misuse of misapplication, while the item (Verify of Implementation matching of approved plans) has come in the last place, this | may due to the fact that many of the plans that have been decided annually must find their way ti implementation and not to falter in their application.

5 - Evaluation field:

Taking into consideration the results of the respondents ' responses, all items getting Weighted mean ranging $(4,174-4$.4349), and getting percentage weight ranging ( 83 . 48 - 86. 98), for that all items remain within the final version of the proposed institutional coordination mechanism, the same as shows in the Table 8 .

Table 8. Distribution of the respondents according to the proposed items of the monitor field

\begin{tabular}{|c|c|c|c|c|}
\hline $\begin{array}{c}\text { Number of item as } \\
\text { important }\end{array}$ & Item & $\begin{array}{l}\text { Number of } \\
\text { items in } \\
\text { questionnaire }\end{array}$ & $\begin{array}{c}\text { Weighte } \\
\text { mean }\end{array}$ & $\begin{array}{l}\text { Percentage } \\
\text { weighte }\end{array}$ \\
\hline 1 & $\begin{array}{l}\text { The evaluation shall be continuous and follow all coordination } \\
\text { processes in the Organization planning, implementation and } \\
\text { monitor }\end{array}$ & 1 & 4.349 & 86.98 \\
\hline 2 & $\begin{array}{l}\text { Measure the farmers reactions to the extension programs } \\
\text { carried out according to the coordination processes between the } \\
\text { agricultural extension and the research and agricultural services }\end{array}$ & 10 & 4.317 & 86.34 \\
\hline 3 & $\begin{array}{l}\text { Determination of farmers ' satisfaction with modern agricultural } \\
\text { techniques published according the coordination between } \\
\text { agricultural extension and research and agricultural services }\end{array}$ & 11 & 4.309 & 86.18 \\
\hline 4.5 & $\begin{array}{l}\text { Verification the feasibility of coordination processes for the target } \\
\text { community }\end{array}$ & 2 & 4.293 & 85.86 \\
\hline 4.5 & $\begin{array}{l}\text { Measuring the changes achieved after the implementation of the } \\
\text { coordination plans on the target community }\end{array}$ & 3 & 4.293 & 85.86 \\
\hline 6 & $\begin{array}{l}\text { Evaluation of means of communication and the agricultural } \\
\text { extension methods and used to disseminate modern technologies }\end{array}$ & 8 & 4.269 & 85.38 \\
\hline 7.5 & $\begin{array}{l}\text { Use evaluation results to make the right decisions about future } \\
\text { coordination processes }\end{array}$ & 5 & 4.253 & 85.06 \\
\hline 7.5 & $\begin{array}{l}\text { Evaluation of modern agricultural techniques published } \\
\text { according to the coordination between agricultural extension , } \\
\text { agricultural researchus and agricultural services }\end{array}$ & 7 & 4.253 & 85.06 \\
\hline 9 & $\begin{array}{l}\text { Evaluation of the results of the extension programs carried out in } \\
\text { accordance with the coordination processes between agricultural } \\
\text { extension, agricultural research and agricultural service } \\
\text { providers }\end{array}$ & 6 & 4.246 & 84.92 \\
\hline 10 & Achieving participation of farmers in evaluation processes & 9 & 4.214 & 84.28 \\
\hline 11 & $\begin{array}{l}\text { Identify the objectives and results of coordination achieved from } \\
\text { others that have not been achieved }\end{array}$ & 4 & 4.174 & 83.48 \\
\hline
\end{tabular}


Table 8 reveals the items (The evaluation shall be continuous and follow all coordination processes in the organization, planning, implementation and monitor ) was ranked first, this may be due to the importance of evaluation for the respondents as the best way to know the deviations in the course of operations and try to correct them at the right times, while the item ( Identify the objectives and results of coordination achieved from others that have not been achieved ) has come at the last place this may be due to the fact that the evaluation process is more conducive to the detection of mistakes and abuse of staff than to the extent to which the goals are achieved. In order to rank the five fields of the institutional coordination mechanism, the results showed that the fields obtained a Weighted range ranging between (4 . 18 - 4 . 27) and percentage weights ranging between $(83,64-85.4)$ as shows in Table 9.

Table 9. Distribution of respondents according to the fields of the proposed mechanism for institutional coordination between agricultural extension and research and agricultural

\begin{tabular}{|ccccc|}
\hline \multicolumn{3}{c}{ Services } \\
\hline Field & Weighte mean & $\begin{array}{c}\text { Percentage } \\
\text { Weighte }\end{array}$ & Fields ranking & Field number in the questionnaire \\
\hline Evaluation & 4.27 & 85.4 & 1 & 5 \\
Implementation & 4.264 & 85.28 & 2 & $\mathbf{3}$ \\
Monitor & 4.24 & $\mathbf{8 4 . 8 1}$ & 3 & 2 \\
Planning & 4.21 & $\mathbf{8 4 . 2 6}$ & 4 & 1 \\
Organization & 4.18 & $\mathbf{8 3 . 6 4}$ & $\mathbf{5}$ & \\
General rete & $\mathbf{4 . 2 3}$ & $\mathbf{8 4 . 6 7}$ & & \\
\hline
\end{tabular}

It is concluded from the table, as a result organizing procedures of the of the high levels of approval obtained coordination process are carried out on a from the research sample, that the small scale in some projects and hypothesis of research is accepted which states that is necessary to create a procedures do not exist, and if they mechanism for the coordination process. It is concluded that the evaluation field proper scientific form . weight of 83.64 degrees this may be due to the fact that the organizing procedures of the coordination process are carried out on small scale in project and, extension programs, But the evaluation procedures do not exist, and if they $\mid$ exist, they do not take place in the proper scientific form Table 9 summarizes the outline of the proposed institutional coordination mechanism of the proposed mechanism as shown in Figure 1, which shows clear lines of coordination and division duties and responsibilities between agricultural extension and various centric agencies related to rural development in Karbala governorate

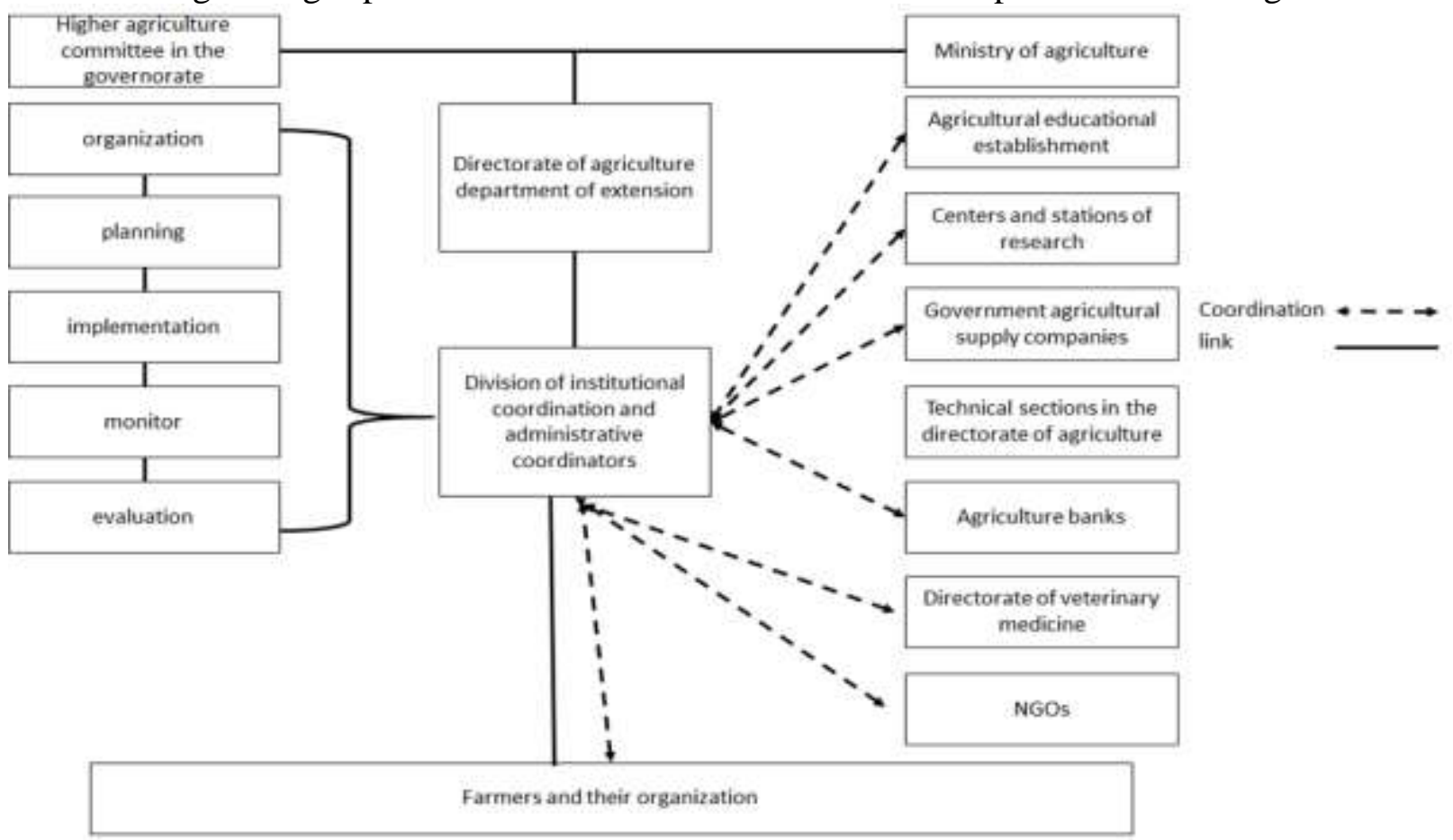

Figure 1. proposal mechanism for coordination 


\section{REFERENCES}

1. Abdel Fattah, Saadia Shukri Ali, 2013, Building Tests and Metrology in Psychology, I 1 , Modern Library of Publishing, Cairo, $p$. 10

2. Aboudi Ali. J.m.2014 the participation of researchers and extension and dissemination of agricultural technology grain crops in Iraq, cairo university.p2.

3. Arab Organization for Agricultural Development 2012, Meeting of Agricultural Technology Transfer Officers and Experts in the Arab World, The Hashemite Kingdom of Jordan, electronic version, in Arabic

4. Ajili sahab. A.yousef. 2006. Development of the organizational structure of agricultural extension in Iraq. Phd thesis. University of Baghdad p121

5. FAO. 1997, Management of the Agricultural research training manual Module 8, research - extension Linkage, Rome, p. 28

6. Al-Farhon, Q.M.2004. A Proposed model for harmonizing agricultural research and application of its technologies in the field. The Iraqi j pf agric. Sci. v35(1).p.171

7. Hamid, A.M, and Adnan Aljadri.1998. Modern agricultural technologies and ways of dissemination, Journal of agric-Iraq. V1,P13

8. Hassan, $\mathrm{Mr}$. Mohamed Abu Hashim, 2006, Psychometric Characteristics of Measuring Instruments in Psychological and Educational Research Using Spss, College of Education , King Saud University, p. 10, in arabic

9. Kirway , T . N ., Lema , N . M , Lyimo, S. D, Kileo, R. 0, Kapange , B. W, Schouten C , and Schrader , T .(Editors) (2003). Farming Systems approaches Training Manual. Module 2 , Interdisciplinary collaboration , Royal Tropical Institute, Tanzania : p . 29

10. Al-Oussi,A.I.2011. The relationship between the roles and functions of workers in research and educational institutions and agriculture extension in the republic of Iraq, Phd thesis, Cairo university p:111-123.

11. Proietti, P. and tudini.L.2013. exposal evaluation of research activates financed by the Tuscany region in the field of viticulture and aquaculture. $21^{\text {st }}$ ESEE European seminar on extension education septmber 2013. Antalya.Turkiey:p215-220

12. Qamar , 2005 , Update of National Extension Systems, Scientific Guide for Policy Makers in Developing Countries Food and Agriculture Organization of the United Nations , Rome , p . 59, in arabic

13. R.M. Ismail.2013. the state of extension planning process in Baghdad agricultural directorate. The Iraqi journal of agriculture science. V44 (6):719-728

14. R.M. I. al-khazraji.2015. A suggested extension plan to exhibition foundation for dates palms and exhibition in al-diwaniya agricultural directorate. The Iraqi $\mathrm{j}$. of agric. Sci. v46(3): 447-456

15. Shaker M.H.2006. The main pillars of the extension service in contemporary variables, the $8^{\text {th }}$ conference of the scientific association for agricultural development of agricultural exports, Cairo, p 108

16. Shammari, K.A. Hussein.2014. The reality of the management of the transfer of protected agricultural technology and dissemination of urban agriculture in Iraq and the level of utilization of their use. Master thesis. University of Baghdad p.118

17. Shammari , Amer Hussein , 2014 , The reality of the Imanagement of the transfer of protected agricultural technology and dissemination of vegetables in Iraq and the level of utilization of their use, MA, Faculty of Agriculture, University of Baghdad, p. 118, in Arabic

18. Swanson, Petron. 1990, Agricultural Extension, Food and Agriculture Organization of the United Nations, Rome, p. 45, in Arabic 19. Swanson, Petron et al ., 1997 , Improving Agricultural Extension, Food and Agriculture Organization of the United Nations, Rome, $\mathrm{p}$ .181 , in Arabic .

20. Taha, Samer Mohi et al . 2008 . A Study or Improving the Management of Agricultural Extension Work in Iraq, Journal of the College of Basic Education, 52, Mustansiriyah University, pp. 593 - 604, in Arabic

21. Zaki, Jamal Zaki, and Sayed Yassin, 1963, Foundations of Social Research, Arab Thought House, Cairo p . 44, in Arabic, 